\title{
Harnessing the Real Estate Market for Equitable Affordable Housing Provision through Land Value Capture: Insights from San Francisco City, California
}

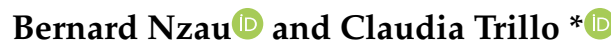 \\ School of the Built Environment, University of Salford, Manchester M5 4WT, UK \\ * Correspondence: C.Trillo2@salford.ac.uk
}

Received: 19 May 2019; Accepted: 27 June 2019; Published: 2 July 2019

\begin{abstract}
Affordable housing remains a serious problem in many countries. Even as the housing affordability crisis deepens, most cities continue to exhibit robust real estate markets with high property prices. The low-income and poor households are unable to access affordable housing and remain excluded. This paper draws from empirical research conducted in the city of San Francisco and focuses on the application of Land Value Capture (LVC) through increased Inclusionary Housing (IH) requirements after plan changes that increased density potential in San Francisco's Eastern Neighbourhoods to evaluate its effects on the goals of increasing both affordable housing and social inclusion. Findings reveal that the increased inclusionary requirements used as LVC mechanism enabled $76.2 \%$ of all the affordable housing units produced in the Eastern Neighbourhoods to be produced by market-rate developers in 2011-2015 as compared to the rest of San Francisco, where $35.5 \%$ of the affordable units were produced from the market through inclusionary policy during the same period. The study demonstrates that upzoning underutilised land coupled with a well-planned LVC mechanism can help harness the strength of the real estate market and increase both affordable housing production and social inclusion.
\end{abstract}

Keywords: affordable housing; inclusionary housing; land value capture; rezoning; social inclusion

\section{Land Value Capture and Affordable Housing}

As the urban population in the world's cities continue to grow, housing affordability challenges continue to persist [1]. Faced with the reality of the critical importance of housing, many countries continue to implement policies to increase stock of affordable housing. However, housing still remains inaccessible and unaffordable in many urban areas [2]. Inequality in the housing market and exclusionary land use policies seriously challenge the achievement of the Sustainable Development Goals, i.e., the United Nation's international agenda adopted in 2015 to achieve sustainable future for all [3]. The Sustainable Development Goal number 11 includes, among its target to be achieved by 2030, to ensure "access for all to adequate, safe and affordable housing and basic services and upgrade slums", to be measured by the proportion of urban population living in slums, informal settlements or inadequate housing. This paper focuses on land value capture (LVC) as a planning tool for harnessing increased land values arising from changing plans or rezoning land to more intensive use (upzoning) for public benefits purpose, in particular, increasing affordable housing provision. Therefore, it offers insights to planners and policy makers seeking to achieve the UN targets on housing affordability.

Land value capture (LVC) has been proposed as an innovative way to generate affordable housing [4-9]. The question of how LVC as a planning tool impacts on the housing development and the housing market continues to stir public debate in many countries [10,11]. Scally and Tighe [12] argue that there still seems to be a disconnect between traditional planning and development processes 
and the most effective and efficient mechanisms for working with communities to promote affordable housing. However, according to Jacobus [13], more and more communities are consciously seeking to develop local policies that promote mixed-income development and tapping increased land values through affordable housing. There is, therefore, a need to focus on the market and rethink the broader set of exclusionary land use policies. These exclusionary land use policies are the primary reason that make housing in many cities so expensive and the problem cannot be fixed unless the housing market itself is fixed [14] (p. 60). Voith and Wachter [5] further indicate that the provision of durably affordable housing is difficult and requires significant intervention in the housing market.

As Calavita [15] points out, LVC has not been, in fact, part of the US planning culture. However, recently, a few cities have begun to engage in LVC, albeit surreptitiously. An increasing number of local governments are relaxing zoning and height restrictions, allowing dense development which are linked to affordability expectations through Inclusionary Housing (IH) policies that condition upzoning on the provision of affordable housing [9].

Although according to some scholars upzoning may create more problems than it solves [16-19], a robust scholarship indicates that a well-designed LVC system can result into higher numbers of affordable housing, thus easing the affordability crisis and enhancing social integration $[9,15,20]$. However, it is not clear in the literature to what extent utilizing LVC through increasing IH requirements produces more affordable housing and enhances social inclusion. The effectiveness of affordable housing delivery as a land value capture mechanism is not so well-documented [21]. Bates [22] identified rezoning combined with programs of inclusionary housing and commercial linkages fees as best practice tools for mitigating the harms of gentrification but there is paucity of studies examining this topic. How such a program affects access to housing for households at various income levels or whether a particular type of rezoning will benefit or burden local residents is not always clear [23]. No research seems to exist offering a systematic and comprehensive assessment of how LVC implemented through increased inclusionary requirements affects $\mathrm{IH}$ goals at the neighbourhood level and particularly comparing the achievement of those goals in different plan areas within neighbourhoods in a city. With respect to these research gaps, this paper offers an original contribution through an in-depth case study of an LVC program, assessing its impacts on IH goals over a significant timeframe. The paper focuses on an innovative program of LVC through increased IH requirements after upzoning San Francisco's Eastern Neighbourhoods to understand the motivation and context under which the tool was implemented. We answer questions regarding why and how the city adopted LVC and the effect it has had on affordable housing production and social inclusion. In so doing, this paper offers valuable insights to the larger international policy makers community, by contributing to fill the current gap in the knowledge regarding how to operationalise the Sustainable Development Goal 11 at the local level and demonstrates the potential of existing planning instruments and tools for the achievement of the UN targets.

As Calavita and Mallach [24] observed, housing provision and land use planning are inextricably linked, since plans designate the amount of land to be dedicated to housing development and lay out the ground rules for that development. Wyatt [21] added that land use regulation limits the supply, and therefore increases the price of land for regulated uses, including housing. Landowners thus receive an unearned increase in their wealth, while at the same time, the cost of housing becomes unaffordable for marginal buyers. Glaeser and Ward [25] found that land use regulations decrease new construction, increase housing prices and disallow communities from maximizing their land values because of density levels that are far too low. Glaeser and Gyourko [26] observed that measures of zoning strictness are highly correlated with high prices. There is, therefore, a need to rethink about the rigidity of plans in a context of changing circumstances, because as Calavita and Mallach [24] (p. 9) argued "when plans create shortages in the supply of land needed to accommodate growth-by reducing or keeping artificially low the quantity or densities of residentially designated land usesthey increase the cost of that land and hence of housing".

Harnessing the benefits of rezoning can best be done through Land Value Capture. Land Value Capture (LVC) means requiring and using for public benefit part of any increment in land value that 
results from public policy and/or investment (and not by direct action by the landowner). According to Calavita and Wolfe [8], LVC - which in the US is variously referred to as Public Benefit Zoning (PBZ), Community Benefits Strategy (CBS) or Public Benefit Bonus (PBB)—is the process of requiring community benefits from land owners whose land has increased in value due to government actions. The concept of LVC is illustrated in Figure 1 below. Interest in LVC has gained momentum because of increased urban population and housing needs coupled with decreasing public resources directed to housing [27]. The idea of LVC was first proposed by John Stuart Mill in 1848, who argued that its practise was merely applying an accession of wealth, created by circumstances, to the benefit of the society, instead of allowing it to become an unearned appendage to the riches of a particular class [28]. This argument for use of LVC was further amplified by Henry George who argued that increases in the value of land should accrue to society as a whole and not to individual owners [29].

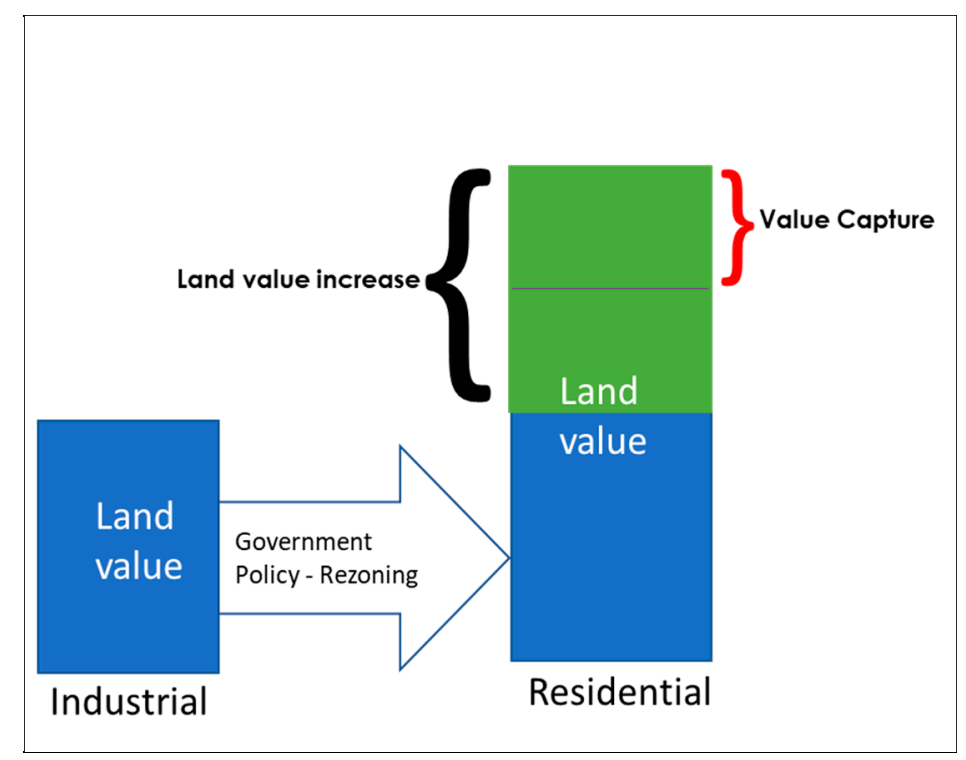

Figure 1. Illustration of Land Value Capture (LVC). Source: Author's Construction.

Fainstein [17] argues that the public sector could take part of the gains in land value through the exercise of its land use regulatory powers. The author reasons that LVC should be used for redistributive purpose as the benefits of urban land ownership should flow to all city users and should be used to redress disadvantage. Many other authors have supported this thinking $[8,27,30-32]$. The notion of value capture is to mobilise for the benefit of the community at large some of the land value increments generated by actions other than those of the landowner. Such actions include changes in land use norms and regulations [33]. Increased land values benefit landowners and can have unintended consequences harmful to low- and moderate-income people, as they can result in displacement, which in turn can mean higher housing and transportation costs, and longer commutes for those families who are forced to move [8]. Ingram and Hong [27] argue that LVC is an efficient and equitable tool because those who did not contribute to the increased land value do not retain all the financial benefits.

Land value is the result of both public and private investment and actions [34]. Therefore, as Ingram and Hong [27] argue, each participant in value creation is entitled to some portion of this value. As the authors argue, LVC does not involve the value related to the original productivity of the land paid for by the owner and the increment in value generated by private land improvements. These should remain in private hands as any value capture mechanism that tried to confiscate all increments from private landowners would eliminate private incentives to invest in land and real estate. In addition, Ingram and Hong [27] add that the allocation of land value increments resulting from long-term trend in population growth and economic development is controversial and, in most 
cases, it is difficult to determine what share of increased land value stems from these. According to the authors, LVC policies focus on the change in value that can be attributed to a particular time-bound action such as rezoning, particularly, upzoning. When land becomes more desirable for a user of higher density development than currently zoned, it requires a change in zoning regulations. When upzoning — or an increase in density_occurs, land becomes more valuable because more development can occur on the same parcel of land [8].

The LVC contemplated in this paper is for the value created by land use regulations. The question that comes to mind is "How then can this be effectively done?" As Ingram and Hong [27] argue, when it comes to capturing land value created by changes in land use regulations, there is no clear consensus. The authors clearly point out that the distribution of regulation related changes in land value is more the result of political manoeuvring and bargaining than of straightforward economic and technical arguments. Booth [35] saw LVC as a straightforward matter and argues that all that needs concern us is the mechanics of the process of the capture as this has remained troublesome. Calavita and Mallach [24] proposed that apart from imposing moderate inclusionary requirements within an existing zoning framework, an additional approach is to link IH and LVC to the ongoing process of land use changes or rezoning. In this case, increased IH explicitly becomes a vehicle for capturing for public benefit some part of the gain in land value resulting from the public action of rezoning or land use changes. There are two conditions identified by Calavita and Wolfe [8] for successful implementation of land use based LVC. First, LVC policy only works well in a strong, or at least stable, real estate market. Secondly, implementation of LVC policy should be done before land is upzoned because it is at the time of plan change or upzoning that those values are solidified.

\section{Inclusionary Housing as an Instrument of Land Value Capture for Affordable Housing Provision}

Calavita and Mallach [24] have defined Inclusionary Housing (IH) as land use regulations that require developers of market-rate residential development to set aside a small portion of their units, usually between 10 and 20 percent, for households unable to afford housing in the market. Alternatively, they can choose to pay a fee or donate land to a municipal land bank or a community development corporation in lieu of providing units. In return, a developer may be granted incentives such as density bonuses [36].

According to Dr. George "Mac" McCarthy, who is the President and CEO of the Lincoln Institute of Land Policy, many jurisdictions practise LVC in many forms without knowing they are doing it. One such way is through Inclusionary Housing also known as inclusionary zoning. During a lecture on 14th February 2017 at the institute in Massachusetts, George clarified that inclusionary zoning is a form of LVC [37]. Inclusionary Housing is an LVC tool because the level of housing affordability required under it is based on the change in land value. As Ingram and Hong [27] argue, the ability to capture the value generated by a flexible zoning scheme is a precondition for the successful implementation of IH requirements. When property prices in the market increase exponentially, and local authorities require provision of inclusive affordable units, it is a way of capturing the land value increment. As Calavita and Mallach [24] (p. 1) argue, IH is a means of using the planning system to create affordable housing by capturing resources created by the marketplace.

The architects of IH were stirred by high housing prices and thought of capturing part of it for public benefit. Calavita and Mallach [24] observed that the extent to which the cost of housing throughout the US, and particularly California, was rising was beyond the reach of the low-income and middle class. This became a rallying call for change and as the authors observed, the precipitous increase in both the volume of market driven construction and the cost of housing also gave increased visibility to the opportunities to leverage the market to create affordable housing, particularly through capture of land value increments that were created by grants of planning permissions. Explaining the growth of IH in California which experienced high property prices and high demand for affordable housing in the 1990s, Calavita and Mallach [24] (p. 72) thus stated: "In this climate of increased demand for affordable housing, growing number of policy makers realised that the extraordinary runup in housing prices meant that the new profitability of private market developments created the 
opportunity to recapture some part of this windfall for affordable housing". The authors argue that unprecedented price appreciation with no parallel increase in public sector support for affordable housing was particularly conducive to the growth of $\mathrm{IH}$. They further argue that such windfall of high returns because of increased prices led to reduced developer opposition to IH. Hickey et al [9] added that the often-voluntary nature of these policies may be a way to introduce $\mathrm{IH}$ policies in places where political, legal and/or market barriers have historically impeded the policy's broader adoption. Tying affordability to upzoning can be an effective means for cities and urban suburbs to harness the energy of the housing market to help address growing affordability challenges [9]. IH may be understood as a new pragmatic approach by governments in their efforts to provide affordable housing, a reaction to diminished public financing for housing due to neo-liberalism policies [38].

Critics have argued that $\mathrm{IH}$ is a tool that tries to solve housing problems generated by the market conditions by employing more market conditions. To a certain extent, $\mathrm{IH}$ means using the market to correct market failures by means of public regulations [38]. IH also works well in hot markets conditions [9] and is largely ineffective in poor market environments [38]. Even in hot markets, they must be carefully designed to avoid negative impacts on the price and supply of housing in the overall market $[9,39]$.

As we have stated earlier, the LVC contemplated by this paper is that which arises from land use changes which lead to increased land value. Such capture is through increased IH requirements. Most IH programs provide cost offsets including density bonuses, fee waivers, modification of development standards, parking reductions and expedited permitting to incentivise developers. This is necessary because as Calavita and Mallach [20] (p. 32) observed, where the inclusionary requirement is being imposed on a pre-existing zoning, the effect is to diminish the value of the land rather than enhance it. Therefore, it would appear that, as the authors rightly argue, it is better to further affordable housing through capture of land value increments in the course of rezoning processes whereby the provision of affordable housing is driven by planning considerations rather than by site-specific offsets.

IH is particularly important as a potential mechanism for LVC. If the relationship between IH and land value was better appreciated, it is possible that political opposition for IH in the US would diminish [20]. IH has emerged as an instrument that equity planners can use to ensure a place for low-income residents in gentrifying neighbourhoods. Optional $\mathrm{IH}$ policies that only apply when a neighbourhood or property is upzoned can enable places to work around legal restrictions that prohibit certain mandatory IH requirements [9].

\section{Research Methodology}

This study was based on a mixed research methodology and a case study strategy. The case of San Francisco's Eastern Neighbourhoods was selected on purpose having met all the main criteria according to a preliminary literature review corroborated with informal interviews with academic experts in the field. First, according to Calavita [15], it could be argued that LVC in the US was invented in San Francisco. Secondly, Brahinsky et al [40], praised the Eastern Neighbourhoods plans as examples of the transformations of plans and regulations to address community needs. Thirdly, LVC has been implemented in the city for a sufficient duration allowing for evaluation of the program and assessment of impacts on affordable housing production and social inclusion.

Secondary data were gathered from San Francisco city offices and websites and the U.S. Census Bureau's American Community Survey, while primary data was gathered through interviews, survey and field observations. Planners, city officials, developers, academics, community leaders and affordable housing advocates were purposively selected. The authors interviewed 12 persons including four local city officials, two academics, two developers and four community advocates/leaders-all familiar with the Eastern Neighbourhood rezoning and its goals.

Data collection was carried out over an 11 months' period from April 2018 to February 2019. Primary data collected from planners and city officials related to the rezoning process (plan preparation) and the IH requirements, outcomes and challenges encountered. Developers were interviewed regarding their participation in program formulation and implementation, their knowledge and 
views on options available to them and feasibility of their projects. Other stakeholders, including academics, community leaders and affordable housing advocates, provided information regarding community participation, their interests and interactions with the planners and city officials. Secondary data included program characteristics, number of both market rate and affordable housing units produced, affordable units produced by market rate developers and affordable units produced using public subsidy.

\section{Setting the Context for the Case Study}

\section{San Francisco Housing Market, Housing Affordability and IH Programs}

San Francisco is located in Northern California on the West Coast of the US and includes significant stretches of the Pacific Ocean and San Francisco Bay as its boundaries. It lies approximately $560 \mathrm{~km}$ north west of Los Angeles City. Tables 1 and 2 below summarises the city's demographic characteristics. San Francisco is a relatively small city, both in area and population with a long tradition of progressive/left politics.

Table 1. Population and Race distribution.

\begin{tabular}{|c|c|c|c|c|c|c|c|c|c|}
\hline \multirow[b]{2}{*}{$\begin{array}{l}\text { Area } \\
\text { (Squae } \\
\text { Miles) }\end{array}$} & \multirow[b]{2}{*}{$\begin{array}{c}\text { Population } \\
\text { (1st July } \\
\text { 2017) }\end{array}$} & \multirow[b]{2}{*}{$\begin{array}{c}\text { Population } \\
\text { Density (1st } \\
\text { July 2017) } \\
\text { People Per } \\
\text { Square Mile }\end{array}$} & \multicolumn{7}{|c|}{ Race Distribution } \\
\hline & & & White & $\begin{array}{c}\text { Black/ } \\
\text { African } \\
\text { American }\end{array}$ & Asian & $\begin{array}{c}\text { Mixed } \\
\text { Race }\end{array}$ & $\begin{array}{c}\text { American } \\
\text { Indians } \\
\text { and } \\
\text { Alaska } \\
\text { Native }\end{array}$ & $\begin{array}{c}\text { Native } \\
\text { Hawaiian } \\
\text { and Other } \\
\text { Pacific } \\
\text { Islanders }\end{array}$ & $\begin{array}{l}\text { Hispanic } \\
\text { or Latino } \\
\text { Origin (Of } \\
\text { any Race) }\end{array}$ \\
\hline 46.87 & 884,363 & 18,868 & $47.2 \%$ & $5.3 \%$ & $34.2 \%$ & $5.1 \%$ & $0.4 \%$ & $0.4 \%$ & $15.3 \%$ \\
\hline
\end{tabular}

Table 2. Age and Gender Distribution.

\begin{tabular}{ccccc}
\hline \multicolumn{3}{c}{ Age and Gender Distribution. } & \multirow{2}{*}{$\begin{array}{c}\text { Population Living below } \\
\text { the Federal Poverty Line }\end{array}$} \\
\cline { 1 - 4 } Under 18 & $\mathbf{6 5}$ or more & Men & Female & $12.5 \%$ \\
\hline $13.5 \%$ & $14.4 \%$ & $51 \%$ & $49 \%$ & $1 \%$ \\
\hline
\end{tabular}

Source: Author's Compilation (Data from US Census Bureau and Worldpopulationreview.com).

As Walker [41] observed, the San Francisco Bay area is going through the worst housing crisis in its history with home prices and rents increasing rapidly. According to the author, San Francisco city in particular remains one of the least affordable housing markets in the country and the world. With its increasing population attracted by a booming economy in both the city and the region, housing demand has continued to increase, making the provision of adequate affordable housing a significant challenge for the city. Contributing to the high demand is the desire by high tech, wealthy employees in Silicon Valley to live in an exciting urban environment.

In 2010, vacancy rates were at $5.4 \%$ for rentals and $2.3 \%$ for homeownership [42]. The median value of owner-occupied housing units in the city is higher than the state's and nation's average as shown in Table 3 below. However, the city has strived to increase affordable housing production over the years and has adopted a general plan, area plans and housing elements which support this goal.

Table 3. Median Value, Median Gross Rent and Home Ownership (2013-2017).

\begin{tabular}{ccccccccc}
\hline \multicolumn{7}{c}{ Market Characteristics in San Francisco (2013-2017). } \\
\hline $\begin{array}{c}\text { Median Value (Owner Occupied } \\
\text { Houses) }\end{array}$ & \multicolumn{3}{c}{ The Median Gross Rent } & \multicolumn{3}{c}{ Home Ownership } \\
\hline $\begin{array}{c}\text { San } \\
\text { Francisco }\end{array}$ & California & US & $\begin{array}{c}\text { San } \\
\text { Francisco }\end{array}$ & California & US & $\begin{array}{c}\text { San } \\
\text { Francisco }\end{array}$ & California & US \\
\hline$\$ 927,400$ & $\$ 443,400$ & $\$ 193,500$ & $\$ 1709$ & $\$ 1358$ & $\$ 982$ & $37.3 \%$ & $54.5 \%$ & $63.8 \%$ \\
\hline \multicolumn{7}{c}{ Source: Author's Compilation (Data from U.S. Census Bureau). } \\
\hline
\end{tabular}


Affordable housing in California is defined as housing which is affordable to and occupied by households of low- and moderate-income and whose total cost does not exceed 30 per cent of the corresponding Area Median Income (AMI) for each income group adjusted for household size. The AMIs for all areas of the country are published annually by the U.S. Department of Housing and Urban Development. For San Francisco city/County, the 2018 AMI was $\$ 118,400$ for a family of four. Moderate-income households' income is between 81 per cent and 120 per cent of AMI and Low-income households' income is below 80 per cent of AMI. The low-income is further categorised into extremely low-income (less than 30 per cent of AMI), very low-income (between 31 and 50 per cent of AMI) and low-income households (between 51 and 80 per cent of AMI). The AMI of $\$ 118,400$ in San Francisco compares to AMI's of $\$ 81,800$ in San Diego and $\$ 69,300$ in Los Angeles, respectively [43].

The IH Program in San Francisco also known as "Below-Market-Rate Program" began in 1992 with the adoption of guidelines that required housing projects with 10 or more units that seek a conditional use (CU) permit or planned unit development (PUD) to set aside a minimum of $10 \%$ of their units as affordable units. These guidelines were legislated into law in 2002 with expansion of the requirement to all projects with 10 or more units. In 2006, the inclusionary requirements were increased to $15 \%$ if units were constructed on-site, and to $20 \%$ if constructed off-site and was applicable to projects of five units or more. In 2013, the inclusionary requirements were changed back to projects with 10 or more units and the on-site requirement went back down to $12 \%$, because the previous requirements did not motivate developers enough [44].

\section{Rezoning and Land Value Capture under the Eastern Neighbourhoods Plans}

\subsection{The Case Study Contextualisation}

The Eastern Neighbourhoods (EN) includes Mission, Showplace Square/Portrero Hill, East Soma, West Soma and the Central Waterfront. This area represents approximately $7 \%$ of the city's total area and is approximately 1500 acres or 607 hectares in net area. The gross area including streets is 2000 acres or 809 hectares [45].

During the 1990s, some areas south of the Market street (SOMA) within the Eastern Neighbourhoods had experienced conflicts between residential and industrial uses. There were rapid increases in real estate values and widespread displacement of families and businesses as new commercial and market rate housing increased fuelled by the internet (dot-com) boom [15,46]. City policies had allowed "live work" spaces in warehouses and industrial structures with a simple conditional use permit, without paying development impact fees and in most cases, these were used only for residential purpose [15]. The area saw a vast amount of change, especially in housing development, because residential use could pay more for land and outbid industrial use. Between 2002 and 2006, approximately 1550 new residential units were constructed, primarily as market-rate ownership and live/work lofts [47]. Additionally, "dot-com" businesses moved into the area, many of which displaced existing jobs and residences. On occasion, conflicts arose between some of these new office or residential uses and previously existing industrial uses, due to noise or other by-products of industrial businesses [47].

Several authors $[15,46,48,49]$ explained how a group called the "Mission Anti-Displacement Coalition" (MAC) was formed to fight the changes occurring in their neighbourhoods. When the city initiated a planning process for those areas, MAC proposed their own plan, called the "People's Plan for Jobs, Housing, and Community". According to Calavita (2014), as part of the People's Plan preparation, the leaders of MAC came up with the idea of "Public Benefit Incentive Zoning" (PBIZ). They argued that increases in density create greater value for land owners and developers and that a portion of this increase should be captured in the form of public benefits that would mitigate the impact of the additional development. The plan included a menu of public benefits, with affordable housing on top of the list. Eventually, the city embraced the concept of PBIZ as part of the planning process for the EN. The San Francisco Planning Department began a community-driven land use planning process intended to permit housing development in some areas which were zoned for industrial use while 
protecting an adequate supply of land and buildings for PDR (production, distribution and repair), employment and businesses. PDR uses are, generally, industrial in nature.

The EN rezoning would allow for building relatively higher-density developments that are well-served by transit and close to Downtown. The plan areas that were primarily previously zoned for industry were planned for urban-mixed-use (allowing for residential and commercial developments). The plans increased permissible heights for different parcels as a proxy for additional intensity of development. PDR uses were maintained in the more traditional industrial zones. The city hired a consultant to prepare a residual land value analysis to estimate the enhanced value from height increases and land-use changes. The analysis showed that residual land values and profitability were generally higher under proposed zonings and requirements than under previous zoning.

In summary, the Eastern Neighbourhoods Plans attempted to balance industrial business and affordable housing, mainly by reserving a certain amount of land for industrial business, but significantly increasing the amount of housing. According to a senior policy analyst of the Planning Department, the idea was to come up with "a smart growth plan to permanently shape the neighbourhoods" and to find the right balance and right mix that will work for residents and businesses of San Francisco [50] (p. 1). The overall bias was toward encouraging affordable housing development while seeking to retain what remained of the area's rapidly diminishing pool of blue-collar jobs [51]. Gabriel Metcalf, deputy director of the San Francisco Planning and Urban Research Association is quoted as having said "the city can have it both ways if planners get it right—enough housing can be built in Eastern Neighbourhoods to ease the citywide shortage, without sacrificing the jobs that are already there. There is no reason to have scarcity of housing. There is no reason to have a conflict between jobs and housing. We need to plan to make sure we are not squandering land uselessly." [50] (p. 1).

The EN Plans (Figure 2) were community driven through public workshops. The Plans established the Eastern Neighbourhoods Citizen's Advisory Committee (EN CAC), consisting of 19 members representing key stakeholders. CAC is the central community advisory body charged with providing input to City agencies and decision makers with regard to all activities related to implementation of the Eastern Neighbourhoods Area Plans. The committee also seeks input and relays information to community members regarding the status of development proposals in the Eastern Neighbourhoods [45].

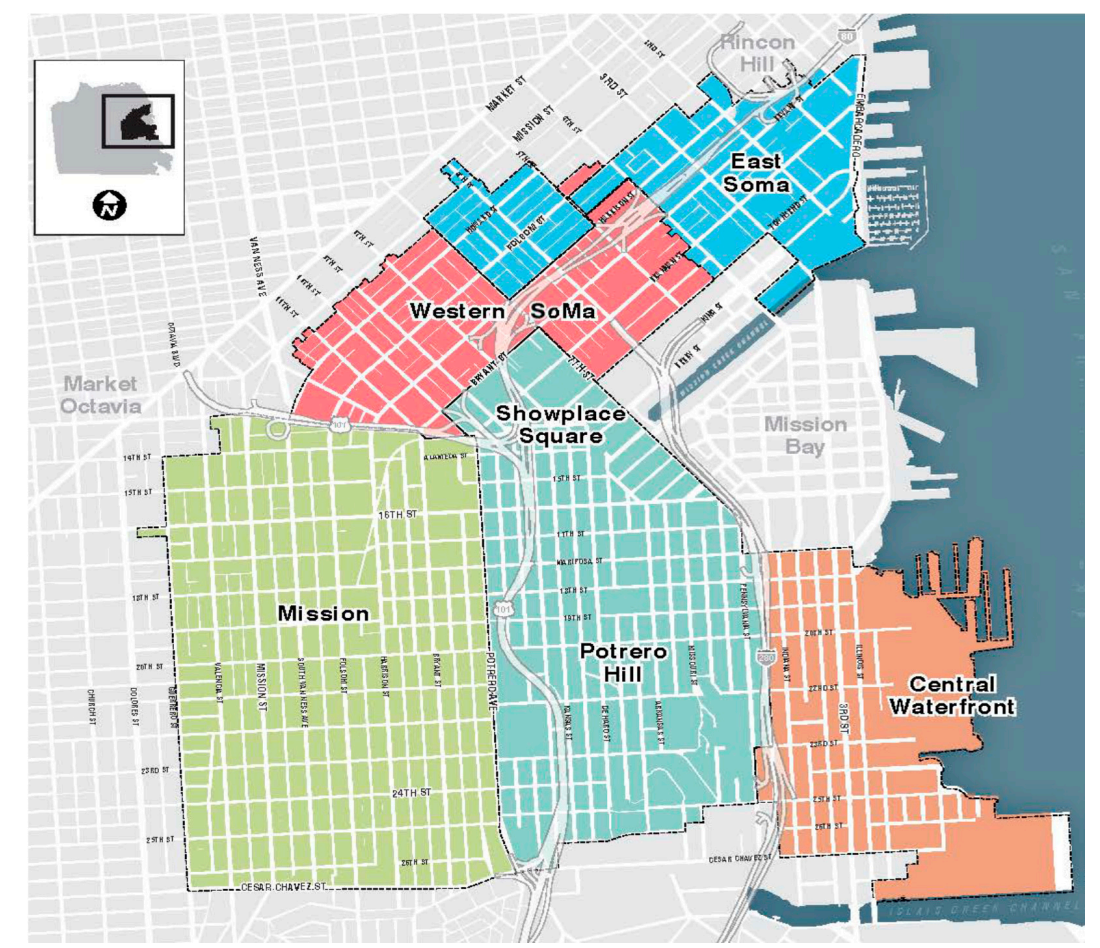

Figure 2. The Eastern Neighbourhoods Plans. Source: San Francisco Planning Department. 


\subsection{Land Value Capture for Affordable Housing Provision under the Plans}

Producing public benefit through LVC can be done through either (1) individual project "deals", utilizing development agreements or similar instruments or (2) establishing at the onset the level of public benefit to be expected, proportional to the benefit received for different parcels, known as the "plan-based" approach [15]. The city of San Francisco chose a plan-based approach to LVC that is based on two primary methods to address the increased need for affordable housing production in the Eastern Neighbourhoods. The first method is increased IH requirements for new zoning districts in formerly industrial areas, requiring deeper affordability and enabling new options outside of current inclusionary options. The plans rezoned many areas that were primarily previously zoned for industry to urban-mixed-use (allowing for residential and commercial developments). The new plans called for increased IH requirements in the formerly industrial zoning districts of the Eastern Neighbourhoods. A new zoning designation of Urban Mixed Use (UMU) required increased affordable housing above the ordinary city's inclusionary program. This district is comprised of areas where market rate housing was formerly permitted only with a conditional use permit. In the new UMU zoning district, market rate housing is now permitted as-of-right provided it is accompanied by an increased amount of below market rate (BMR) housing. This is through increased inclusionary requirements as shown in Tables 4 and 5. The increased housing requirements are based on the fact that land values are increased by allowing additional heights and the removal of conditional use requirements for housing. The second method is through requiring additional fees. The impact fees resulting from upzoning may be directed towards construction of new housing and preservation of affordability of existing housing within the plan areas. These two methods-affordability and fee requirements-are summarised in Tables 4 and 5 below.

(a) Table 4 shows requirements in existing Residential and Commercial Zones where the focus was towards improving neighbourhoods.

(b) Table 5 below shows requirements in formerly Industrial Zones where the focus was towards expanding affordability.

Table 4. Rezoning Fees and inclusionary requirements for existing residential/commercial zones.

\begin{tabular}{ccccccc}
\hline TIER. & DESCRIPTION & RESID FEE & COMM FEE & $\begin{array}{c}\text { INCLUSIONARY } \\
\text { REQUIREMENT }\end{array}$ & $\begin{array}{c}\text { MIDDLE } \\
\text { INCOME }\end{array}$ & $\begin{array}{c}\text { LAND } \\
\text { DEDICATION }\end{array}$ \\
\hline 1 & $\begin{array}{c}\text { Projects without } \\
\text { height increase }\end{array}$ & $\$ 8$ & $\$ 16$ & $\begin{array}{l}15 \% \text { onsite } \\
20 \% \text { offsite }\end{array}$ & $\times$ & $\times$ \\
\hline 2 & $\begin{array}{c}\text { Projects with 1-2 } \\
\text { story height } \\
\text { increase }\end{array}$ & $\$ 12$ & $\$ 20$ & $\begin{array}{l}15 \% \text { onsite } \\
20 \% \text { offsite }\end{array}$ & $\times$ & $\times$ \\
\hline 3 & $\begin{array}{c}\text { Projects with 3+ } \\
\text { height increase }\end{array}$ & $\$ 16$ & $\$ 24$ & $\begin{array}{l}15 \% \text { onsite } \\
20 \% \text { offsite }\end{array}$ & $\times$ & $\times$ \\
\hline
\end{tabular}

Source: San Francisco Planning Department.

According to the San Francisco Planning Department [45], the land dedication affordability option enables developers with large sites in the UMU district to dedicate a portion of the proposed development site to the Mayor's Office of Housing for the development of affordable housing, in substitution of traditional inclusionary requirements. Moreover, while the City's inclusionary program provides a modest amount of housing for those at the lower income groups, there are no programs to address "middle-income" people who earn between 120 and 150 of San Francisco Median Income (SFMI), which is far less than the 200 per cent of SFMI required to purchase the average priced home. The middle-income option is intended to address this gap and allows developers to opt to provide a higher number of affordable units at a higher price, affordable to households with incomes averaging at 135 per cent of SFMI, in substitution of traditional inclusionary requirements. Developers would be able to price units at their discretion to be affordable to households earning between 120-150 per cent of SFMI as long as the average equalled 135 per cent of SFMI, in order to 
differentiate among unit prices and avoid being too close in price to the market rate units. The resulting market-produced units would address the exodus of small families unable to afford a home in the city, without requiring any public subsidy. The risk that market forces could cause prices to escalate out of control is avoided by the average income cap placed at 135 per cent of SFMI. It is worthy emphasising that the middle-income option provides units for purchase only and not for renting.

Table 5. Rezoning Fees and inclusionary requirements for formerly industrial zones. UMU: Urban Mixed Use. Source: San Francisco Planning Department.

\begin{tabular}{|c|c|c|c|c|c|c|}
\hline \multirow[b]{2}{*}{ TIER. } & \multirow[b]{2}{*}{ DESCRIPTION } & \multirow[b]{2}{*}{ RESID FEE } & \multirow[b]{2}{*}{ COMM FEE } & \multirow{2}{*}{$\begin{array}{l}\text { INCLUSIONARY } \\
\text { REQUIREMENT }\end{array}$} & \multicolumn{2}{|c|}{ ALTERNATIVES } \\
\hline & & & & & $\begin{array}{l}\text { MIDDLE } \\
\text { INCOME }\end{array}$ & $\begin{array}{c}\text { LAND } \\
\text { DEDICATION }\end{array}$ \\
\hline A & $\begin{array}{l}\text { UMU/Projects } \\
\text { without height } \\
\text { increase }\end{array}$ & $\$ 8$ & $\$ 16$ & $\begin{array}{l}18 \% \text { onsite } \\
23 \% \text { offsite }\end{array}$ & $30-40 \%$ & $35 \%$ \\
\hline B & $\begin{array}{l}\text { UMU/Projects } \\
\text { with 1-2 story } \\
\text { height increase }\end{array}$ & $\$ 8$ & $\$ 20$ & $\begin{array}{l}20 \% \text { onsite } \\
25 \% \text { offsite }\end{array}$ & $40-50 \%$ & $40 \%$ \\
\hline $\mathrm{C}$ & $\begin{array}{l}\text { UMU/Projects } \\
\text { with } 3+\text { height } \\
\text { increase; other } \\
\text { designated } \\
\text { districts }\end{array}$ & $\$ 8$ & $\$ 24$ & $\begin{array}{l}22 \% \text { onsite } \\
27 \% \text { offsite }\end{array}$ & $50-60 \%$ & $50 \%$ \\
\hline
\end{tabular}

\section{Data Presentation and Discussion}

Interviews with city officials revealed that the Eastern Neighbourhoods area plans placed a high priority on the production of affordable housing as demanded by the communities in the neighbourhoods during the planning process. Officials confirmed that on top of the upzoning, the plans removed density controls and parking requirements in most zoning districts, particularly those well-served by public transit and pedestrian and bike infrastructure.

We looked at the housing production data between 2011 and 2015 city wide and within the Eastern Neighbourhoods. We chose this period because of two reasons. First, by the time the rezoning was done in 2008, the U.S. economy had gone into a recession caused largely by a collapse of the national housing market but by 2011, the market had begun recovering and has rebounded quite strongly since then. Second, the city had reliable data on housing production between 2011 and 2015. To begin with, we sought to understand the overall production of affordable units in the city compared to the Eastern Neighbourhoods. San Francisco produced 2497 affordable units between 2011 and 2015. Out of this, 290 units or 11.6\% were produced in the Eastern Neighbourhoods. This is shown in Figure 3 below.

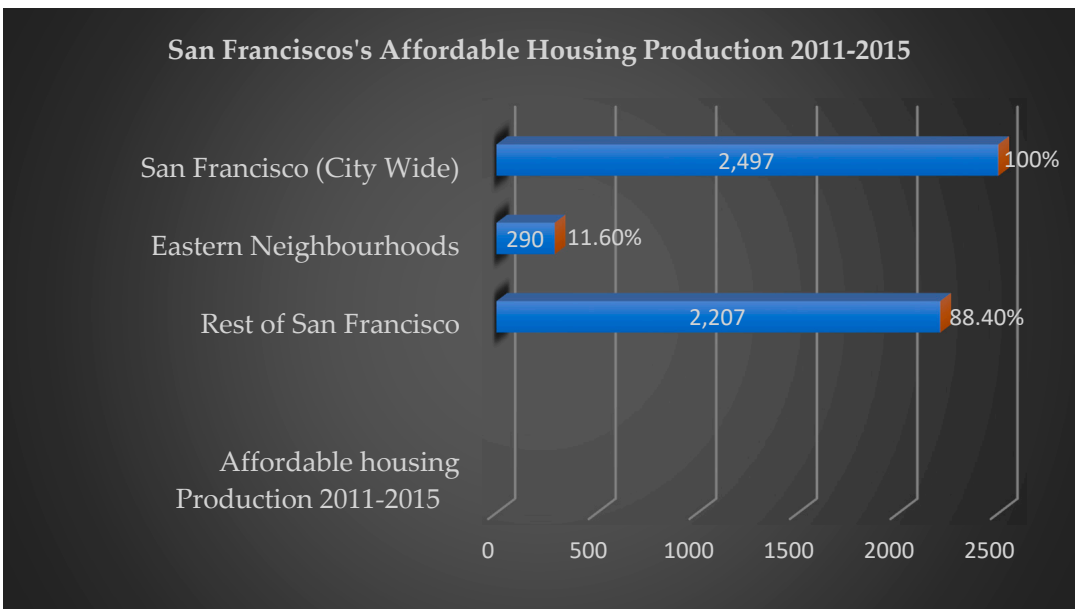

Source: Authors' elaboration based on data provided by the City of San Francisco.

Figure 3. Affordable housing units produced in San Francisco in 2011-2015. 
We sought to understand the programs that provide affordable housing and their respective contribution. Affordable housing in the city is produced either through city funding or by market-rate developers through the inclusionary policy. We found that citywide, out of the 2497 affordable units produced, $1644(65.8 \%)$ were city funded whereas $853(34.2 \%)$ were market-funded through the inclusionary policy. Out of the 290 affordable units produced in the Eastern Neighbourhoods, $221(76.2 \%)$ were produced from the market by for-profit developers whereas $69(23.8 \%)$ were funded with public subsidies. For the rest of San Francisco, out of 2207 affordable units, 1575 units (64.5\%) were city-funded and 632 units (35.5\%) were market-funded through the inclusionary policy. Figure 4 shows the proportion of city funded units versus market funded affordable units (produced through inclusionary policy) in the Eastern Neighbourhoods, the rest of San Francisco and Citywide. It is shown that there was a higher percentage of affordable units built by the market-rate developers through the inclusionary policy in the Eastern Neighbourhoods compared to the rest of the city. $76.2 \%$ of all the affordable units produced in the Eastern Neighbourhoods were financed by the market, built by market-rate developers through the inclusionary policy. Once again, this is significant when compared to the rest of San Francisco and citywide scenarios, where 35.5\% and 34.2\%, respectively, of the affordable units were produced from the market through inclusionary policy.

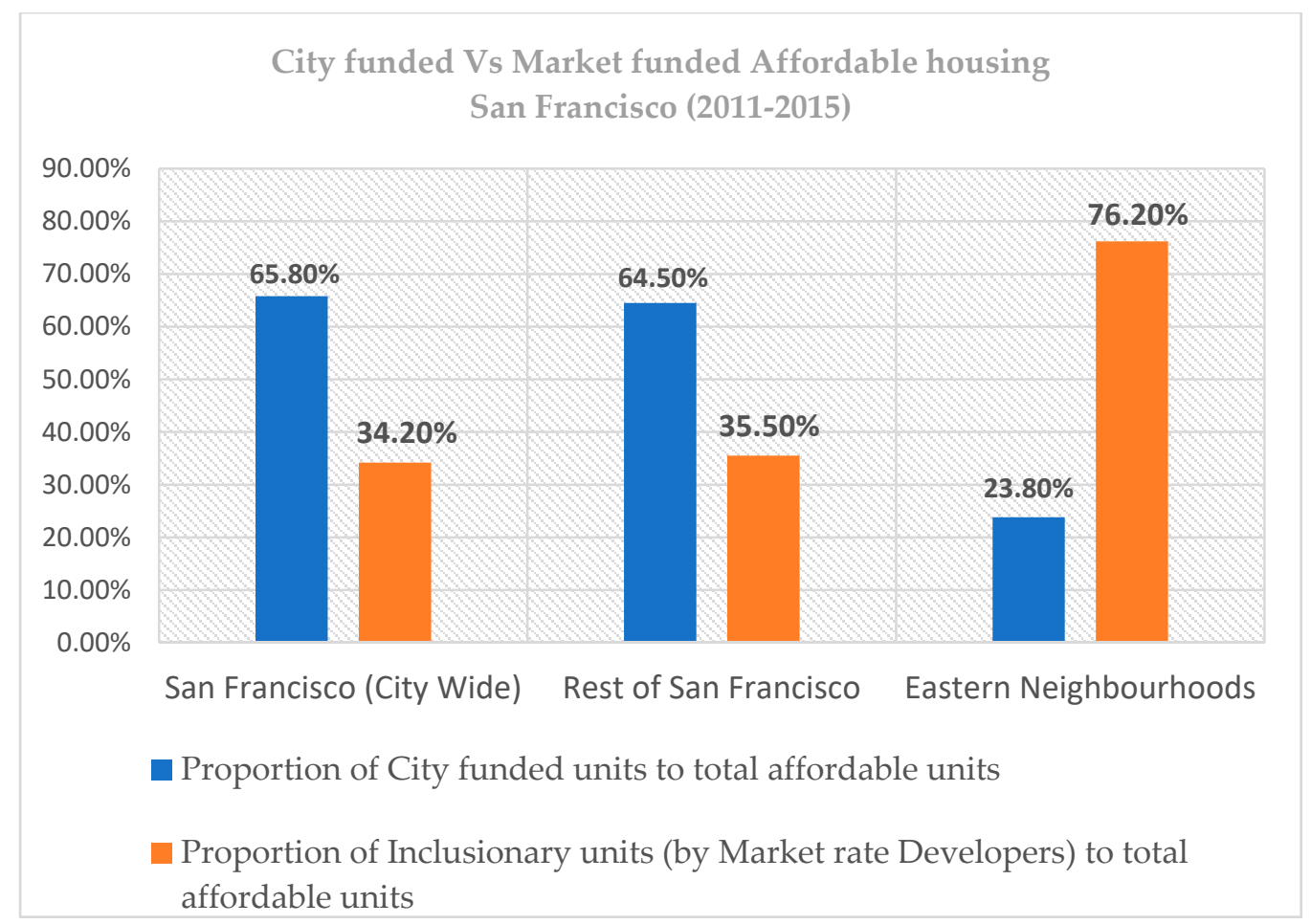

Source: Authors' elaboration based on data provided by the City of San Francisco

Figure 4. Comparing the proportion of city funded and market funded affordable housing.

The contribution of the market to affordable housing within the EN within the period is larger considering affordable housing in-lieu fees that are paid by developers who choose not to produce on-site affordable units. These in-lieu fees form part of the funds which are used to produce city funded affordable units. Within the period 2011-2015, 17 projects within the Eastern Neighbourhoods paid a total in-lieu fees of US\$ 41,029,643. According to San Francisco Planning Department [52], new affordable units are estimated to cost roughly $\$ 550,000$ in construction costs (not including land). This is based on rough estimates based on recent projects that have received assistance from the city. Therefore, the US $\$ 41,029,643$ "in-lieu fees" collected if used to build projects on publicly controlled land, could yield an additional 80 affordable units. This means in essence; therefore, the market 
contribution in EN under the inclusionary program is much greater than the $76.2 \%$ because of the contribution of the in-lieu fees to the city funded units. If the approximated 80 units were to be included in our analysis, it would push the contribution of the market to affordable housing provision in EN to $81 \%$. However, it is important to note that in most cases, in-lieu fees and other city funds are leveraged to access external funding, such as Federal Low-Income Housing Tax Credits, allocated by the State. When this happens, it results into more than double the number of units constructed [51]. Therefore, our hypothetical analysis of 80 additional units ignores this leverage because we wanted to show the actual contribution of the market without any public funding. This analysis also assumes that the 80 units would be constructed within the EN because there is no requirement under the San Francisco IH policy requiring in-lieu fees to be spent to build units within the neighbourhood they originated from.

Citywide, San Francisco produced 853 inclusionary affordable units in 2011-2015. Out of these, 221 units or 26\% were produced in the Eastern Neighbourhoods (See Figure 5). Given that the Eastern Neighbourhoods occupy approximately $7 \%$ of the total land area in the city [45], this is quite a significant contribution. Figure 6 compares the proportion of $\mathrm{IH}$ produced to proportion of land size.

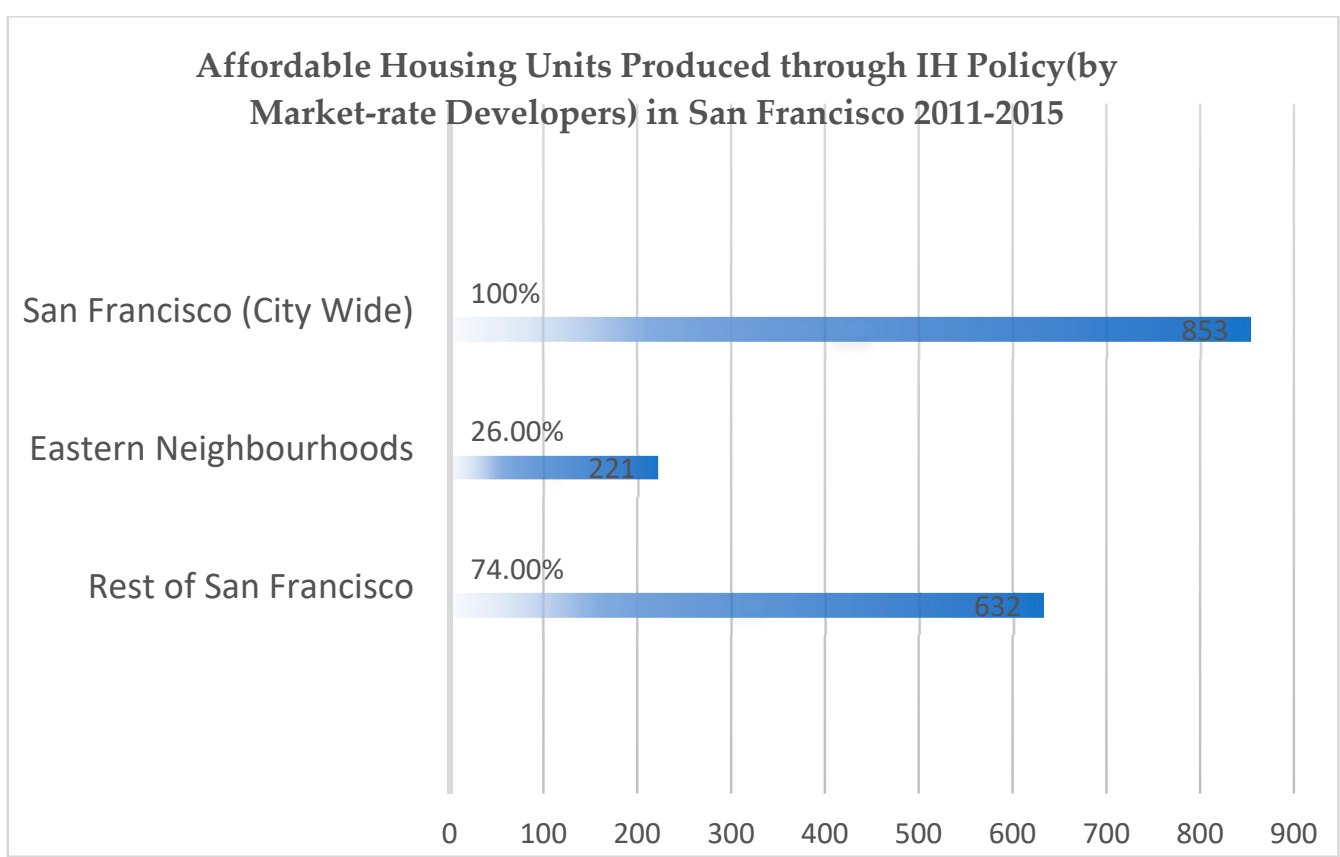

Source: Authors' elaboration based on Data provided by the City of San Francisco

Figure 5. Inclusionary Housing (IH) units produced in San Francisco in 2011-2015.

Proportion of Inclusionary housing units

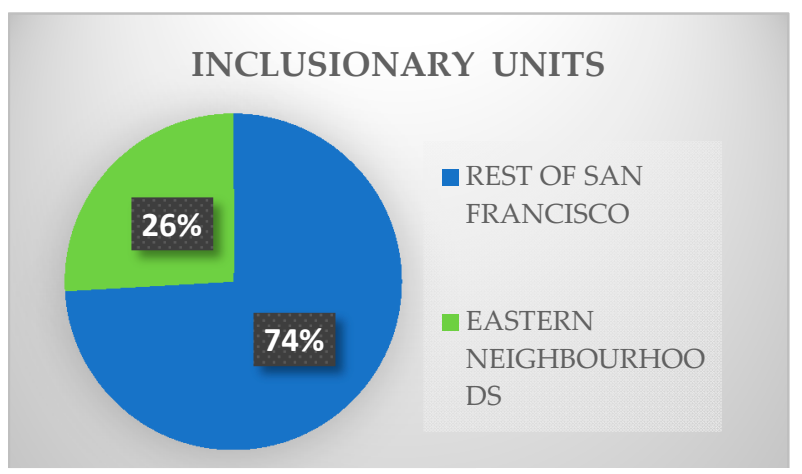

Proportion of Land size

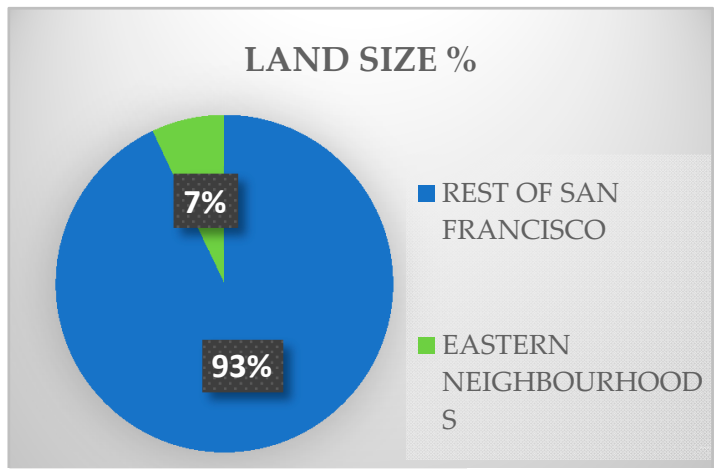

Source: Authors' claboration based on data provided by the City of San Francisco.

Figure 6. Comparing proportion of IH produced in San Francisco to proportion of land size. 
We also found that the rezoning and the resultant LVC through increased IH has resulted in increased social class inclusivity within the communities, if inclusivity is measured by the proportion of affordable units within market-rate developments. This approach of measuring inclusivity has been used in other studies [53,54]. Interviews with officials indicated that prior to the implementation of the Eastern Neighbourhoods plans, housing production in EN was mostly market rate units. Now, this scenario has changed, and Eastern Neighbourhoods are more inclusive as compared to the city average. The city's inclusionary policy by the time, required affordable units to be provided at $12 \%$ of the total housing units produced by market-rate developers. In the EN, inclusionary affordable units were $20 \%$ on average with some plan areas reporting more than four times the legal requirement. For the rest of San Francisco, inclusionary affordable units were at $10.9 \%$, while citywide, the average inclusionary level was $12.4 \%$ propelled by the Eastern Neighbourhoods' production. These analyses are shown in Figure 7 below.

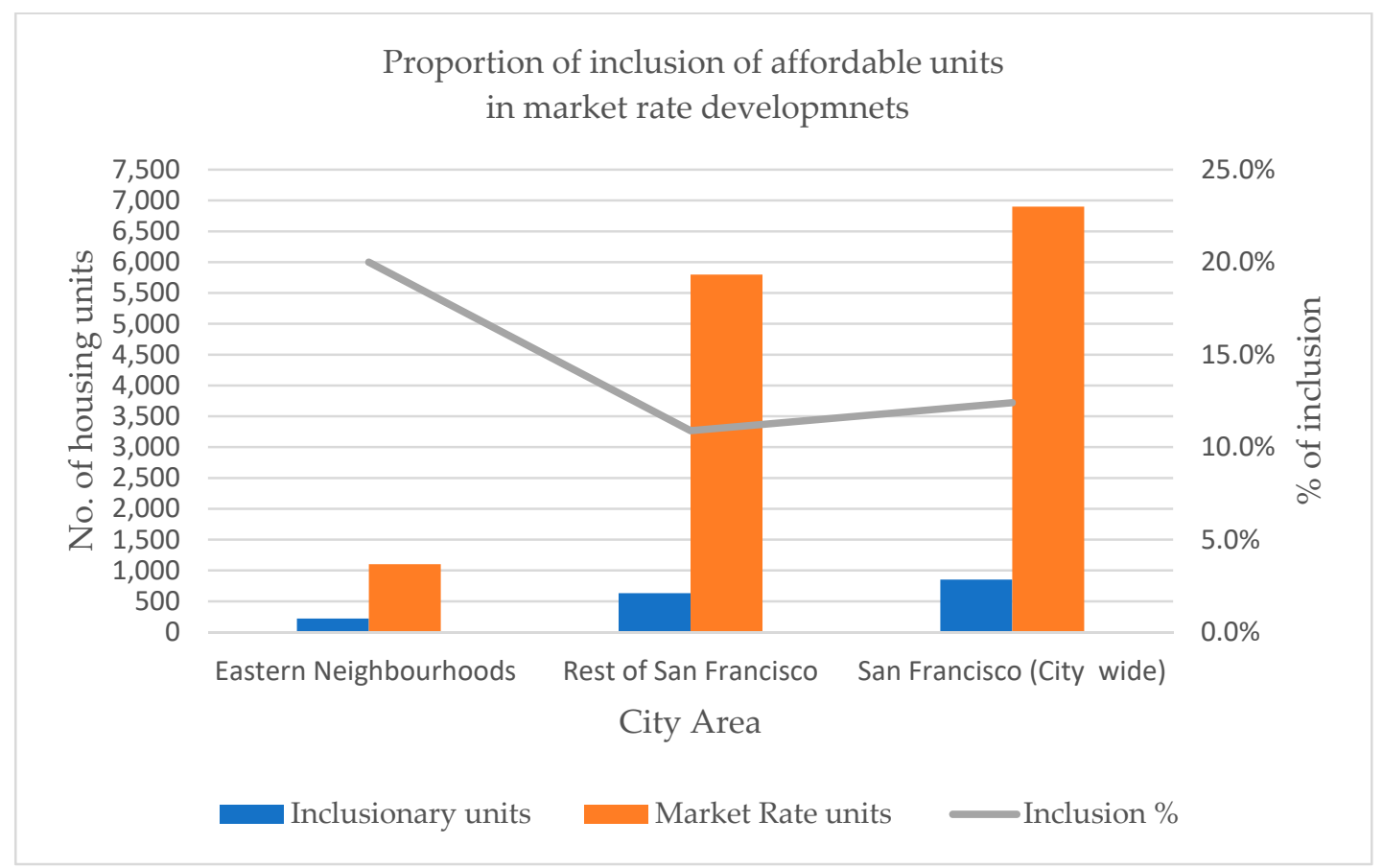

Source: Authors' elaboration based on Data provided by the City of San Francisco.

Figure 7. Comparing the level of inclusion of affordable units in market rate developments.

Table 6 and Figure 8 below shows the percentage of market rate units to total housing units in the eastern neighbourhoods, the rest of San Francisco and citywide. Areas with high levels of inclusion of affordable housing in market rate developments also have a higher proportion of market rate units to the total housing production. The Eastern Neighbourhoods had the highest proportion of market rate units compared to the total housing produced at 79.2\%, with the rest of San Francisco and San Francisco citywide were at $72.4 \%$ and $73.4 \%$, respectively.

Our analyses further found that there were significant differences in affordable housing production and levels of inclusivity among the five plan areas of Eastern Neighbourhoods (Mission, Showplace Square/Portero Hill, East SoMa, West Soma and Central Waterfront). Central Waterfront had the highest inclusion of affordable units into market units at $50.4 \%$, while East Soma recorded $22.6 \%$ inclusion, followed by Mission at $12.5 \%$, Western Soma at $8.6 \%$ and Showplace Square/Portero Hill at 3.6\% (See Figure 9). 
Table 6. Comparing the level of inclusion of affordable units in market rate developments and proportion of market rate units to total units produced.

\begin{tabular}{|c|c|c|c|c|}
\hline & $\begin{array}{c}\text { Total Affordable } \\
\text { Units }\end{array}$ & Market Rate Units & $\begin{array}{c}\text { Inclusion } \\
\text { (Proportion of } \\
\text { Affordable Units } \\
\text { in Market Rate } \\
\text { Developments) }\end{array}$ & $\begin{array}{c}\text { Proportion of } \\
\text { Market Rate Units } \\
\text { to Total Units } \\
\text { Produced }\end{array}$ \\
\hline $\begin{array}{c}\text { Eastern } \\
\text { Neighbourhoods }\end{array}$ & 290 & 1102 & $20.0 \%$ & $79.2 \%$ \\
\hline $\begin{array}{l}\text { Rest of San } \\
\text { Francisco }\end{array}$ & 2207 & 5799 & $10.9 \%$ & $72.4 \%$ \\
\hline $\begin{array}{c}\text { San Francisco (City } \\
\text { wide) }\end{array}$ & 2497 & 6901 & $12.4 \%$ & $73.4 \%$ \\
\hline
\end{tabular}

Source: Author's Compilation (Data from US Census Bureau).

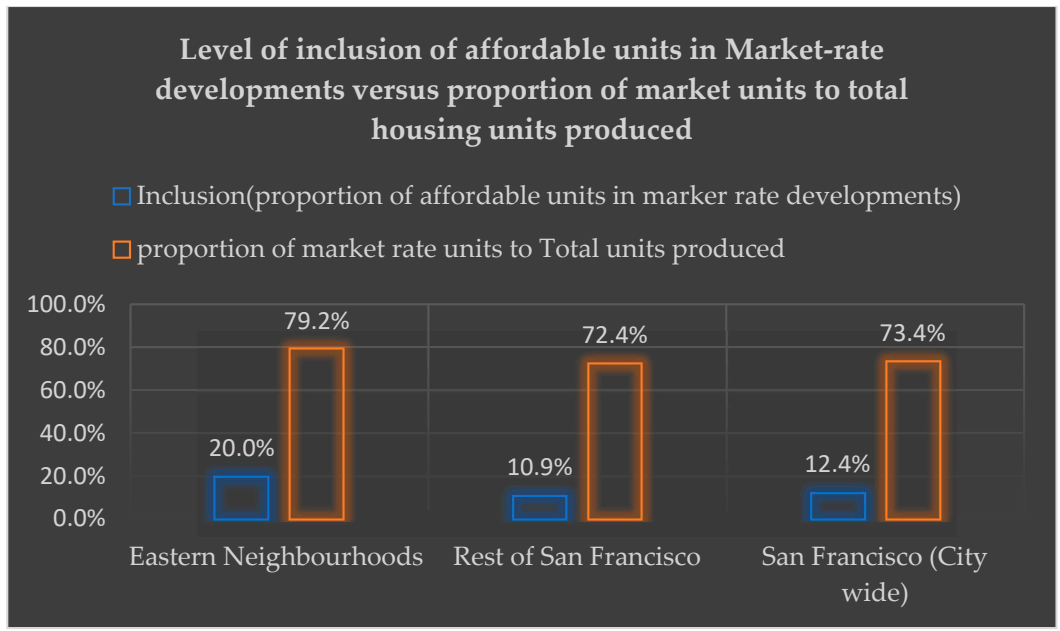

Source: Authors' elaboration based on Data provided by the City of San Francisco.

Figure 8. Comparing the level of inclusion of affordable units in market rate developments and proportion of market rate units to total units produced.

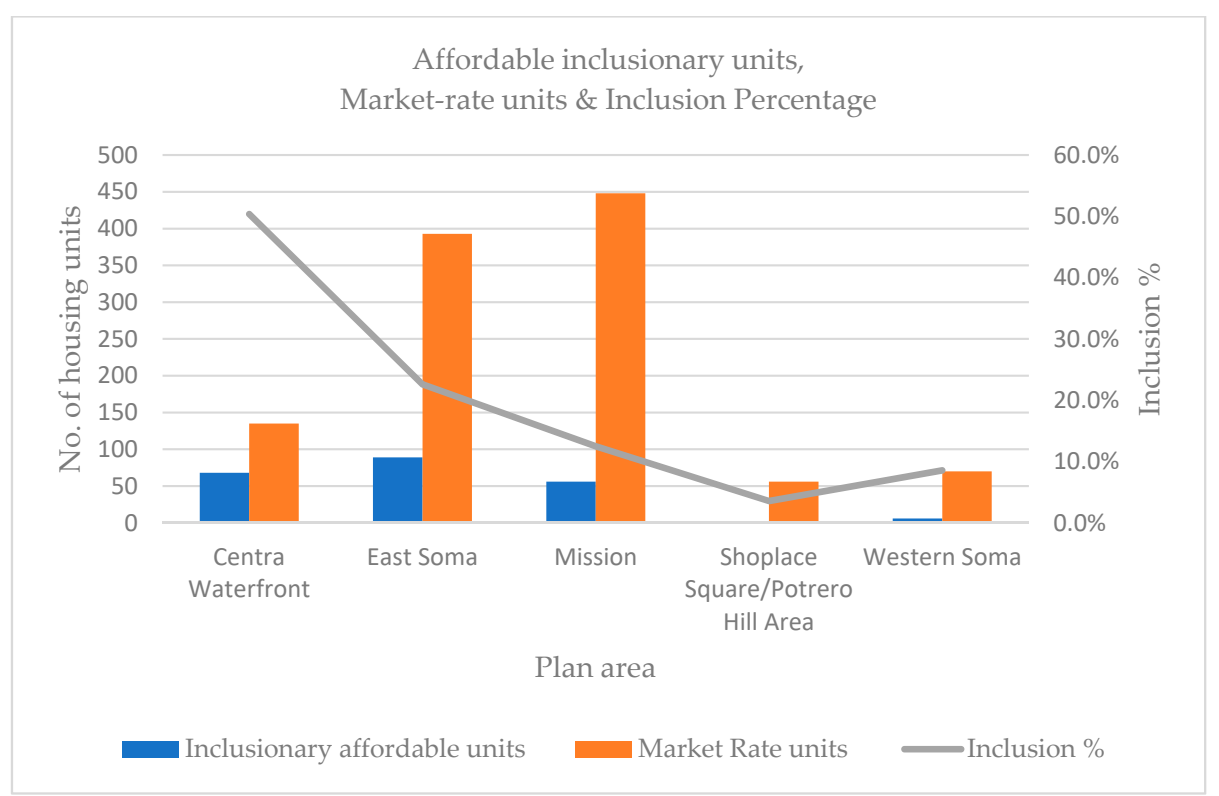

Source: Authors' elaboration based on data provided by the City of San Francisco.

Figure 9. Market rate units, Affordable IH units, and Inclusion percentage in Eastern neighbourhoods. 
We sought to understand the above dynamics with quantitative data triangulated and complemented with qualitative data, gathered through field observations and semi-structured interviews with local decision makers, planners, experts, developers and community leaders. Interviews confirmed that the program has been successful in capturing land value for affordable housing provision with increased inclusion of low-income earners among market rate residents in most areas. However, the following reasons were identified for the differences in amount of affordable housing and levels of inclusion of affordable units within market-rate units in the different plan areas.

(a) Size and intensity of Urban Mixed Use (UMU) zoning.

Areas which had large urban mixed used (UMU) districts and where former industrial areas use lost a higher percentage of land to UMU had a higher inclusion of affordable units. This is because of the enhanced inclusionary requirements applied to the UMU districts. There is currently a strong market development activity particularly of high-rise residential development in the Central Waterfront plan area which had the highest inclusivity of affordable units. Areas with significantly higher densities and height recorded higher affordable housing production.

(b) Level of office development within Urban Mixed Use (UMU) Districts.

Areas with low levels of office development within the UMU Districts had a higher percentage of IH. There is noticeably less office development in the Central waterfront which had the highest percentage of IH. East Soma plan area produced the highest number of affordable units but compared to the market rate units, its percentage of IH was less than for the Central waterfront. Because of East Soma's close proximity to Downtown, more office development was recorded with value being captured through impact fees and Jobs-housing Linkage fees. See Table 7 below where the contribution of East Soma in terms of impact fees and Jobs-housing Linkage fees is significantly higher than other areas.

Table 7. In-lieu fees, Jobs Housing Linkage fees and Impact fees collected in EN.

\begin{tabular}{cccccc}
\hline & EAST SOMA & $\begin{array}{c}\text { CENTRAL } \\
\text { WATERFRONT }\end{array}$ & MISSION & $\begin{array}{c}\text { SHOWPLACE SQUARE/ } \\
\text { POTRERO HILL }\end{array}$ & WESTERN SOMA \\
\hline $\begin{array}{l}\text { In-lieu fees }(\$) \\
\text { Jobs Housing }\end{array}$ & $11,511,743$ & $21,503,695$ & $7,313,592$ & $1,293,902$ & 917,881 \\
Linkage fees $(\$)$ & $15,200,000$ & 911,848 & 899,747 & 478,509 & $1,300,000$ \\
Impact fees $(\$)$ & $14,635,000$ & $10,034,000$ & $5,357,000$ & $11,384,000$ & $6,940,000$ \\
\hline & Sourre & & & & \\
\end{tabular}

Source: Authors' elaboration based on data provided by the City of San Francisco.

(c) Percentage of Market-rate projects paying in-lieu fees in the plan area.

Areas with high percentages of in-lieu projects had lower percentage of IH. As shown in Figure 10 below, Showplace square/Portrero Hill plan area which had the highest percentage of market-rate projects paying in-lieu fees at $75 \%$ had the lowest percentage of $\mathrm{IH}$ at $3 \%$. Central Waterfront plan area, which had the lowest percentage of projects paying in-lieu fees at $17 \%$, had the highest percentage of $\mathrm{IH}$ at $50.4 \%$. This pattern remains true for the other plan areas except the Western Soma plan area. For the Western Soma area, the inclusion was not as high as expected compared to the percentage of market-rate projects paying in-lieu fees, because most market-rate projects in Western Soma were done outside areas which required increased inclusionary requirement.

(d) Desirability of the Planning area

Developers indicated that there are certain areas preferred by housing consumers because of the desirability of the neighbourhoods. As investors, they would, therefore, prefer building in such areas even when the inclusionary requirements are high compared to an alternative with low inclusionary requirements because it guarantees fast uptake of the market housing units. Central Waterfront, which had the highest percentage of $\mathrm{IH}$, is a very desirable area because it fronts the San Francisco Bay and has infrastructure that supports and encourages transit use, walking and biking. 


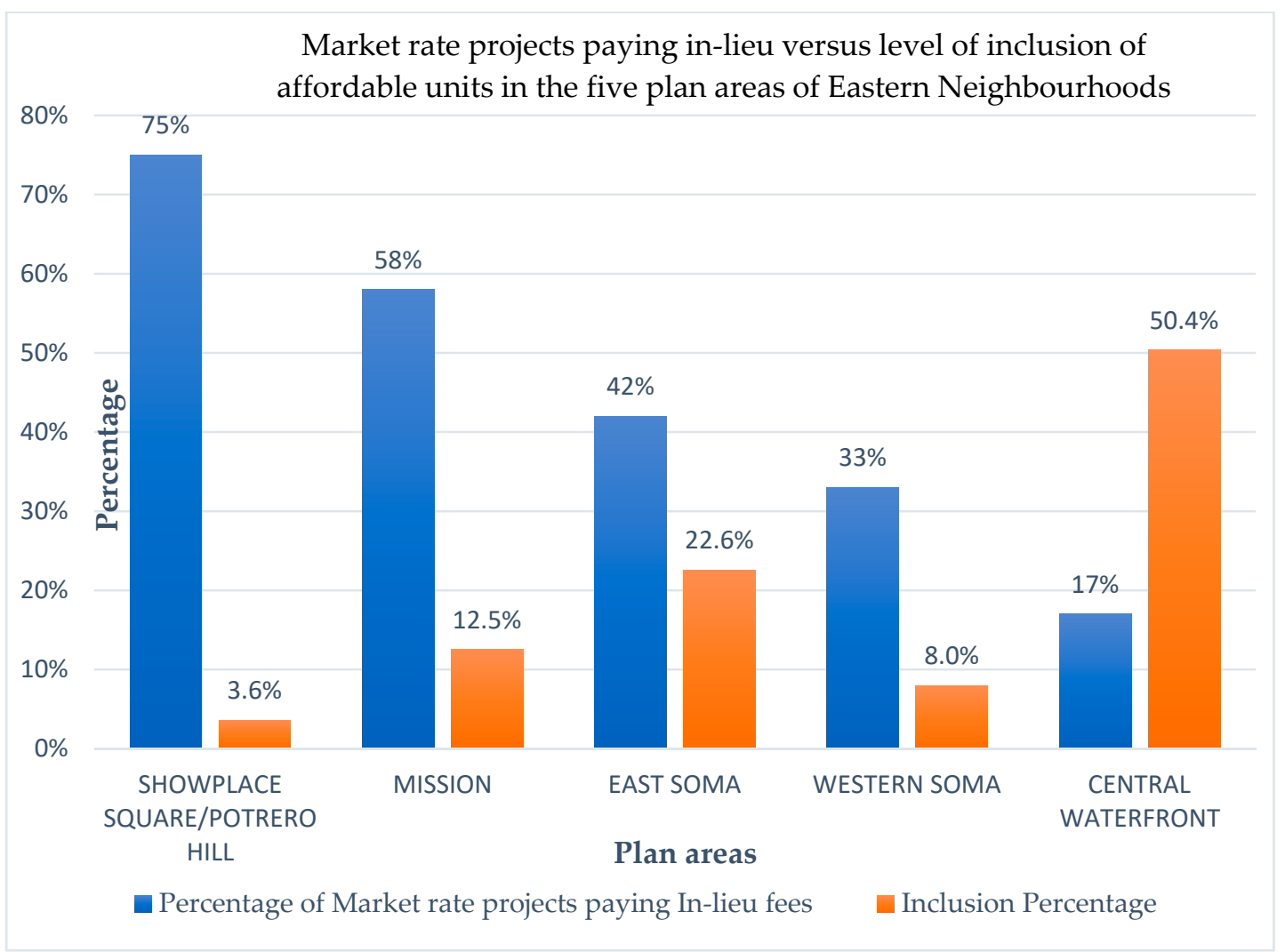

Source: Authors Compilation with Data from City of Francisco.

Figure 10. Comparing market rate projects paying in-lieu fees and inclusion percentages.

(e) Existing housing stock under rent control

In some plan areas, such as East Soma and Western Soma, most of the existing housing stock as at the time of plan implementation was under rental control. Interviews revealed that because residential conversions of rent-controlled units are strongly discouraged, this hampered redevelopment of properties by market rate developers who could have provided new and more affordable units through the market.

Interviews with developers confirmed that LVC for affordable housing provision through enhanced inclusionary requirements does not deprive developers of adequate returns on their investments. Developers were found to have embraced the program with increased projects in the EN. Developers interviewed agreed that the rezoning had brought a windfall of increased returns and did not find the increased inclusionary housing requirement economically burdensome to fulfil. City officials also attributed the positive response from developers to the residual land value analysis undertaken by the city consultants showing the enhanced returns following the upzoning. Planners also attributed the success to the plan-based approach to land value capture adopted by the city because it created certainty in stakeholders. To them, it worked far better than any negotiation could. Community leaders interviewed indicated they felt their interests were secured when the level of benefits was decided upfront rather than through negotiation and development agreements which could be politically influenced. Developers also indicated that it is a better way for them than negotiating case by case as it gave them certainty about what they are required to contribute. They felt they were protected from future community demands and also found that it led to faster delivery of projects.

Field observations (Figure 11a,b) confirmed that most of the new developments were found to have utilised the maximum development as permitted under the rezoning although developing below the maximum allowed is an option which developers could take. This clearly demonstrates that the practice 
on the ground of capturing values provided a push to developers to develop to achieve maximum returns and cushion themselves from economic losses, therefore encouraging highest and best use of land.

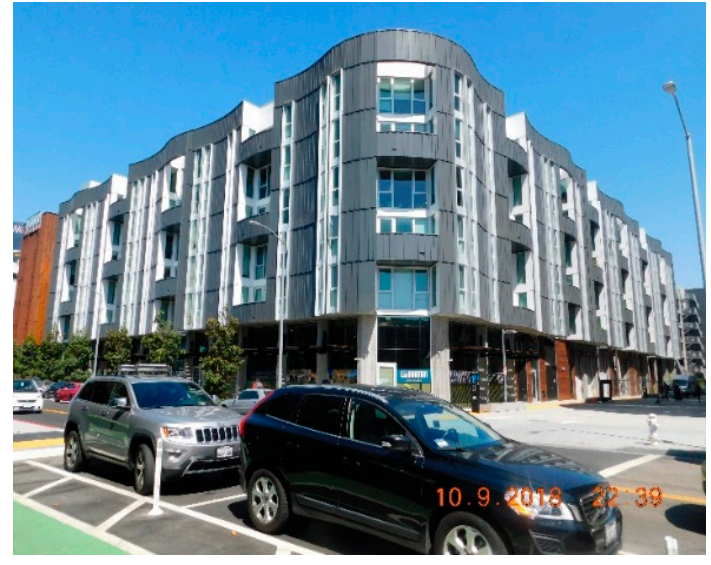

(a)

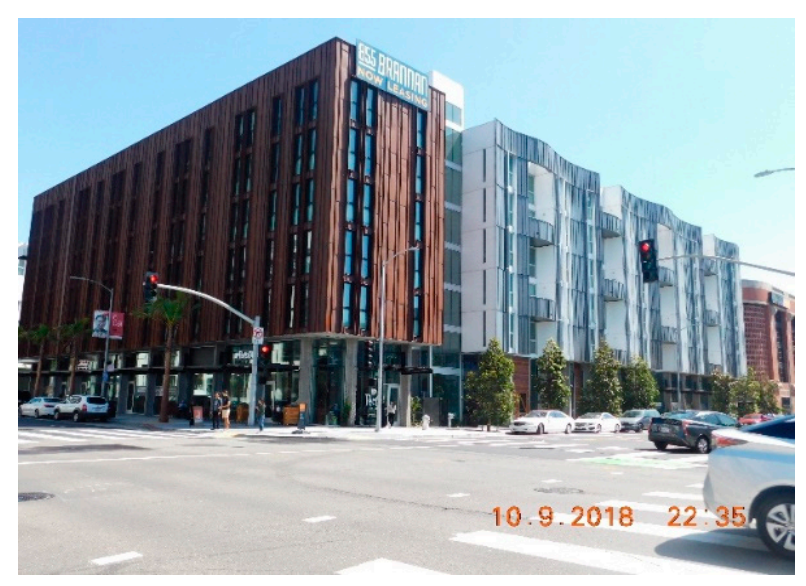

(b)

Source: photos by authors, September 2018.

Figure 11. Developments in the Eastern Neighbourhoods, San Francisco. (a): Side view of 855 Brannan Street Apartments; (b): Front view of 855 Brannan Street Apartments.

\section{Findings and Conclusions}

This paper provides new evidence on how Land Value Capture (LVC) is effective as a planning tool for harnessing increased land values for affordable housing provision thus contributing to increased housing affordability and achievement of one of the targets set by the UN within the Sustainable Development Goals agenda (target 11.1, SDG 11). This has been achieved by drawing from the upzoning of San Francisco's Eastern Neighbourhoods providing evidence that LVC was successful in increasing affordable housing production within market rate developments. It was found that the increased inclusionary requirements used as a LVC mechanism enabled $76.2 \%$ of all the affordable units produced in the Eastern Neighbourhoods to be financed by the market through market-rate developers in 2011-2015. This is significant when compared to the rest of San Francisco and citywide scenarios where $35.5 \%$ and $34.2 \%$, respectively, of the affordable units were produced from the market through inclusionary policy during the same period. The Eastern Neighbourhoods occupy approximately $7 \%$ of the total land area in the city yet they produced $26 \%$ of all affordable housing produced in the city, implying that capturing land value increases as a result of new plans for underutilised areas upzoned to land uses in demand, especially residential, has a huge potential to increase affordable housing and social inclusion. As many neighbourhoods in SF experience gentrification, it becomes very important to make sure that a significant portion of the housing remains affordable in perpetuity, thus avoiding a complete turnover of neighbourhoods to market-rate housing. Increasing the percentage of affordable housing through inclusionary policy is in many cases the only alternative.

Evidence from the quantitative and qualitative data shows that:

(1) Housing production and the level of affordable housing inclusion in market rate developments was found to depend on the size and intensity of residential zoning, the level of development of competing uses like offices in mixed use zones, the number of market-rate projects paying in-lieu fees, the desirability of the planning areas and the existing housing stock under rent control. An implication of the findings is that planners should specify goals of development types, in addition to density targets, when upzoning planning areas. Ensuring highest and best use of land should be encouraged in residential areas as it has the effect of increasing both market 
rate and affordable housing. In mixed use zoning, there is a need for a clear balance between the competing uses to be set during the planning phase to ensure program goals of increasing affordable housing is achieved. To ensure balanced growth across neighbourhoods, investment in infrastructure and other facilities that attract private investment should be prioritised. Projects paying in-lieu fees have the effect of reducing the rate of inclusion of affordable units in a plan area. If the goal of increasing social inclusivity is to be achieved fairly in all areas, then there is probably a need to limit the number of projects paying in lieu fees. Alternatively, the city could mandate that the in-lieu-fees be spent close to where they originated. The policy of discouraging conversions of residential housing under rent control may need to be revised particularly in areas where there is likely to be more affordable housing delivered through the market.

(2) The success of any program of LVC will depend on the involvement of multiple participants across different segments of the society. The support of city leaders, policy makers, the community and developers is very critical. City leaders and decision makers will have to engage in progressive politics and balance between the interests of different groups pulling in different directions. Community involvement in planning for the rezoning in EN was found to be crucial in ensuring success of the program because residents were able to propose LVC (which they called Public Benefit Zoning) for public benefits with affordable housing topping the priority list.

(3) LVC for affordable housing provision through enhanced inclusionary requirements does not deprive developers of adequate returns on their investments as confirmed from developers in the Eastern Neighbourhoods. However, studies undertaken by the city consultants showing the enhanced land values after the upzoning were found to have motivated developers. Introduction of LVC policy should be grounded on a sound framework based on economic analysis of the nexus between change in value due to a public policy (e.g., rezoning) and the requirement for affordable housing provision. The aim here is to guarantee sustainability by ensuring that any value increase leading to capture is based on economic analysis.

(4) The city of San Francisco used a plan-based approach to LVC in EN. A plan-based approach to LVC for affordable housing provision creates certainty in stakeholders and is likely to be more successful for the city than a negotiation approach.

(5) LVC encourages highest and best use of land as most of the new developments were found to have utilised the maximum development as permitted under the rezoning. Bringing land to its highest and best use not only increases both market-rate and affordable housing, but also has a multiplier effect on neighbourhood businesses and jobs.

(6) When upzoning a neighbourhood for affordable housing provision, it is important to design a program of preferential treatment to existing residents and households when allocating the affordable units to safeguard against the threat of displacement and gentrification.

(7) San Francisco has successfully implemented LVC without a specific legislation backing the same but has relied on existing legal framework. It can, therefore, be concluded that the existing legal frameworks in place may be able to support land value capture to harness the strength of real estate markets for affordable housing provision.

The evaluation of the LVC upon upzoning of the Eastern Neighbourhoods offers valuable insights to planners and policy makers internationally. Some limitations of this study should be taken into account though. There could be limitations to the transferability given that San Francisco is a vibrant city with a strong economy supported by the technology industry and during the period studied the city was experiencing unprecedented demand for housing. Cities intending to use a similar model will need to evaluate the soundness of their property markets to guarantee the desired demand for effective implementation of such a program.

The strength of this program lies in its use of the zoning powers which is not anticipated to be impractical in many cities. Almost universally, zoning ordinances give cities enormous powers, which in most cases are untapped for affordable housing provision. 
Based on the above findings and conclusions and bearing in mind the identified limitations, this research offers valuable lessons on using LVC upon upzoning for equitable affordable housing provision applicable to the wider international context.

Author Contributions: This paper is based on Bernard Nzau's PhD work. He prepared the draft and data collection under the MAPS-LED project; Claudia Trillo is the PhD supervisor and the MAPS-LED project UK coordinator, managed the grant and revised the draft. An earlier version of this paper was presented by Bernard Nzau at the World Bank Conference on Land and Poverty; Washington DC, USA held on 25-29 March 2019.

Funding: EC H2020 MAPS-LED research project (Grant No. 645651).

Acknowledgments: This paper builds on the fieldwork conducted by the authors within the H2020 MAPS LED project, Call H2020-EU.1.3.3._Stimulating innovation by means of cross-fertilisation of knowledge Project ID: 645651. The authors thank the San Diego State University for the support received in the fieldwork and in particular Professor Nico Calavita for the valuable insights provided.

Conflicts of Interest: The authors declare no conflict of interest. The funder had no role in the design of the study; in the collection, analyses, or interpretation of data; in the writing of the manuscript, or in the decision to publish the results.

\section{References}

1. UN Habitat. World Cities Report, Urbanization and Development: Emerging Futures; UN Habitat: Nairobi, Kenya, 2016.

2. World Bank. Housing: Unavailable and Unaffordable; Kenya Economic Update: Washington, DC, USA, 2017.

3. UN. About the Sustainable Development Goals. 2015. Available online: https://www.un.org/ sustainabledevelopment/sustainable-development-goals/ (accessed on 8 March 2019).

4. Lincoln Institute of Land Policy. How Cities Can Unlock Land Value to Create Affordable Housing. 2017. Available online: https://www.lincolninst.edu/news/lincoln-house-blog/how-cities-can-unlock-land-valuecreate-affordable-housing (accessed on 9 January 2019).

5. Voith, R.P.; Wachter, S.M. The Affordability Challenge: Inclusionary Housing and Community Land Trusts in a Federal System. In Value Capture and Land Policies, Proceedings of the 2011 Land Policy Conference, Cambridge, Mass, USA, 2011; Ingram, G.K., Hong, Y.-H., Eds.; Lincoln Institute of Land Policy: Cambridge, MA, USA, 2012.

6. Germán, L.; Bernstein Allison, E. Policy Brief: Land Value Capture Tools to Finance Our Urban Future Lincoln Institute of Land Policy. 2018. Available online: https://www.lincolninst.edu/sites/default/files/ pubfiles/land-value-capture-policy-brief.pdf (accessed on 9 January 2019).

7. Rosen, D.; Lake-Brown, N.; Glascock, B. How Value Capture Can Create Affordable Housing: Video Lecture at Lincoln Institute of Land Policy; Lincoln Institute of Land Policy: Washington, DC, USA, 2017. Available online: https://www.lincolninst.edu/publications/multimedia/how-value-capture-can-create-affordable-housing (accessed on 9 January 2019).

8. Calavita, N.; Wolfe, M. White Paper on the Theory, Economics and Practice of Public Benefits Zoning. 2014. Available online: http://ebho.org/wp-content/uploads/2011/09/LVR-White-Paper-Full_141113.pdf (accessed on 9 January).

9. Hickey, R.; Sturtevant, L.; Thaden, E. Achieving Lasting Affordability through Inclusionary Housing; Lincoln Institute of Land Policy Working Paper; Lincoln Institute of Land Policy: Washington, DC, USA, 2014.

10. Gurran, N.; Bramley, G. Urban Planning and the Housing Market: International Perspectives for Policy and Practice; Macmillan Publishers Ltd.: London, UK, 2017.

11. Finch, P.; Melvin, J.; Sandhu, H. “Opinion: Land Value Capture Idea Gaining Traction as Housing Affordability Crisis Continues; BC Government \& Service Employees" Union; Vancouver Courier. 7 January 2019. Available online: https://www.vancourier.com/real-estate/opinion-land-value-capture-idea-gainingtraction-as-housing-affordability-crisis-continues-1.23578245 (accessed on 9 January 2019).

12. Scally, C.P.N.; Tighe, J.R. Democracy in Action? NIMBY as Impediment to Equitable Affordable Housing Siting. Hous. Stud. 2015, 30, 749-769. [CrossRef]

13. Jacobus, R. Inclusionary Housing: Creating and Maintaining Equitable Communities; Lincoln Institute of Land Policy: Cambridge, MA, USA, 2015. Available online: https://www.lincolninst.edu/sites/default/files/pubfiles/ inclusionary-housing-full_0.pdf (accessed on 2 December 2018). 
14. Metcalf, G. Sand Castles before the Tide? Affordable Housing in Expensive Cities. J. Econ. Perspect. 2018, 32, 59-80.

15. Calavita, N. Land Value Recapture in the US: The Case of San Francisco. Adv. Eng. Forum 2014, 11, 330-337. [CrossRef]

16. Angotti, T. Zoned Out in the City: New York City's Tale of Race and Displacement; Poverty \& Race Research Action Council: Washington, DC, USA, 2017; Volume 26, p. 20036.

17. Fainstein, S.S. Land Value Capture and Justice. In Inclusionary Housing in International Perspective: Affordable Housing, Social Inclusion, and Land Value Recapture; Lincoln Institute of Land Policy: Washington, DC, USA, 2010.

18. Goldberg, L. Game of Zones: Neighborhood Rezonings and Uneven Urban Growth in Bloomberg's New York City. Master's Thesis, Massachusetts Institute of Technology, Cambridge, MA, USA, 2015.

19. Shelton, J. The Cost of Affordability: Inclusionary Zoning and Displacement in East New York; Metropolitisc.org. 2018. Available online: https://www.metropolitiques.eu/The-Cost-of-AffordabilityInclusionary-Zoning-and-Displacement-in-East-New-York.html (accessed on 7 January 2019).

20. Calavita, N.; Mallach, A. Inclusionary Housing, Incentives, and Land Value Recapture; Land Lines, Lincoln Institute of Land Policy: Washington, DC, USA, 2009.

21. Wyatt, P. Can land value uplift deliver affordable housing? Experiences from England. J. Eur. Real Estate Res. 2018, 11, 87-101. [CrossRef]

22. Bates, L.K. Gentrification and Displacement Study: Implementing an Equitable and Inclusive Development Strategy in the Context of Gentrification; Portland State University: Portland, OR, USA, 2013.

23. Armstrong, A.; Been, V.; Madar, J.; McDonnell, S. How Have Recent Rezonings Affected the City's Ability to Grow? The Furman Center for Real Estate and Urban Policy; New York University: New York, NY, USA, 2010.

24. Calavita, N.; Mallach, A. Inclusionary Housing in International Perspective: Affordable Housing, Social Inclusion, and Land Value Recapture; Lincoln Institute of Land Policy: Washington, DC, USA, 2010.

25. Glaeser, E.L.; Gyourko, J. The Impact of Zoning on Housing Affordability; Working Paper 8835; National Bureau of Economic Research: Cambridge, MA, USA, 2002. Available online: http://www.nber.org/papers/w8835 (accessed on 20 June 2019).

26. Glaeser, E.L.; Ward, B.A. The causes and consequences of land use regulation: Evidence from Greater Boston. J. Urban Econ. 2008, 65, 265-278. [CrossRef]

27. Ingram, G.K.; Hong, Y.-H. Land Value Capture: Types and Outcomes. In Value Capture and Land Policies, Proceedings of the 2011 Land Policy Conference, Cambridge, Mass, USA, 2011; Lincoln Institute of Land Policy: Washington, DC, USA, 2012.

28. Mill, J.S. Principles of Political Economy with Some of Their Applications to Social Philosophy; Edition of 2004 published by Indianapolis, IN, USA; Hackett Publishing Company: Indianapolis, IN, USA, 2004.

29. George, H. Progress and Poverty: An Inquiry into the Cause of Industrial Depressions and of Increase of Want with Increase of Wealth; The Remedy; Doubleday: Garden City, NY, USA, 1879. Available online: http://www.econlib.org/library/YPDBooks/George/grgPP27.html (accessed on 7 January 2019).

30. Kitchen, H. Property tax: A situational analysis and overview. In A Primer on Property Tax Administration and Policy; McCluskey, W.J., Cornia, G.C., Walters, L.C., Eds.; Blackwell Publishers: West Sussex, UK, 2013; pp. 1-40.

31. Mathur, S. Land value capture to fund public transportation infrastructure: Examination of joint development projects' revenue yield and stability. Transp. Policy 2013, 30, 327-335. [CrossRef]

32. Walters, L.C. Land Value Capture in Policy and Practice. In Proceedings of the World Bank Conference, Washington, DC, USA, 23-26 April 2012. Available online: http://www.landandpoverty.com/agenda/pdfs/ paper/walters_full_paper.pdf (accessed on 7 November 2018).

33. Smolka, M.O. Implementing Value Capture in Latin America: Policies and Tools for Urban Development; Lincoln Institute of Land Policy: Cambridge, MA, USA, 2013.

34. Hong, Y.; Brubaker, D. Integrating the Proposed Property Tax with the Public Leasehold System. In China's Local Public Finance in Transition (165-90); Man, J.Y., Hong, Y., Eds.; Lincoln Institute of Land Policy: Cambridge, MA, USA, 2010.

35. Booth, P.A. The unearned increment: Property and the Capture of Betterment Value in Britain and France. In Inclusionary Housing in International Perspective: Affordable Housing, Social Inclusion, and Land Value Recapture; Lincoln Institute of Land Policy: Washington, DC, USA, 2012.

36. Mallach, A. A Decent Home: Planning, Building, and Preserving Affordable Housing; Chicago Planners Press, University of Chicago Press: Chicago, IL, USA, 2009. 
37. McCarthy, G. Lecture. 2017. Available online: https://www.lincolninst.edu/es/courses-events/courses/howvalue-capture-can-create-affordable-housing (accessed on 8 December 2018).

38. Ponce, S.J. Foreword to Inclusionary Housing in International Perspective: Affordable Housing, Social Inclusion and Land Value Recapture; Calavita, N., Mallach, A., Eds.; Lincoln Institute of Land Policy: Cambridge, MA, USA, 2010.

39. Schuetz, J.; Meltzer, R.; Been, V. 31 Flavors of Inclusionary Zoning: Comparing Policies from San Francisco, Washington, DC, and Suburban Boston. J. Am. Plan. Assoc. 2009, 75, 441-456. [CrossRef]

40. Brahinsky, R.; Chion, M.; Feldstein, L.M. Reflections on Community Planning in San Francisco. Spatial justice. 2013. Available online: http://www.jssj.org (accessed on 7 January 2019).

41. Walker, R.A. Pictures of a Gone City: Tech and the Dark Side of Prosperity in the San Francisco Bay Area; PM Press: Oakland, CA, USA, 2018.

42. City of San Francisco, The Housing Element. 2014. Available online: http://generalplan.sfplanning.org/ 2014HousingElement-AllParts_ADOPTED_web.pdf (accessed on 9 January 2019).

43. U.S. Department of Housing and Urban Development 2018. Available online: https://www.huduser.gov/ portal/datasets/il/il2018/2018summary.odn (accessed on 9 January 2019).

44. San Francisco Planning Department. 2017 San Francisco Housing Inventory; San Francisco Planning Department: San Francisco, CA, USA, 2017.

45. San Francisco Planning Department. East Soma Plan; San Francisco Planning Department: San Francisco, CA, USA, 2008.

46. Zuk, M.; Chapple, K.N. Case Studies on Gentrification and Displacement in the San Francisco Bay Area. Centre for Community Innovation, University of California, Berkeley. 2015. Available online: https://www.urbandisplacement.org/sites/default/files/images/case_studies_on_gentrification_and_ displacement__full_report.pdf (accessed on 9 January 2019).

47. San Francisco Planning Department 2018. Available online: https://sfplanning.org/eastern-neighborhoodscitizens-advisory-committee (accessed on 7 January 2019).

48. Casique, F.D. Race, Space, and Contestation: Gentrification in San Francisco's Latina/o Mission District, 1998-2002. Ph.D. Thesis, University of California, Berkeley, CA, USA, 2013.

49. Opillard, F. Resisting the Politics of Displacement in the San Francisco Bay Area: Anti-gentrification Activism in the Tech Boom 2.0. Eur. J. Am. Stud. 2015, 10, 3. [CrossRef]

50. Kim, R. "Planners Look Hard at S.F.'s East Flank; Rezoning Will Decide What's in, What's Not," SF Gate. 30 March 2002. Available online: http://www.sfgate.com/news/article/Planners-look-hard-at-S-F-s-eastflank2860022.php (accessed on 2 July 2018).

51. Smolka Martim, O. Implementing Value Capture in Latin America: Policies and Tools for Urban Development; Lincoln Institute of Land Policy113 Brattle Street Cambridge, MA 02138-3400 USA. Beitel, K. 2013. “Rezoning the Eastern Neighborhoods in Early 2000s", FoundSF. Available online: http://www.foundsf.org/index.php? title=Rezoning_the_Eastern_Neighborhoods_in_Early_2000s (accessed on 12 February 2019).

52. San Francisco Planning Department. Eastern Neighbourhoods Monitoring Reports; San Francisco Planning Department: San Francisco, CA, USA, 2016.

53. Schwartz, H.L.; Ecola, L.; Leuschner, K.J.; Kofner, A. Is inclusionary Zoning Inclusionary? 2012. Available online: https://www.rand.org/content/dam/rand/pubs/technical_reports/2012/RAND_TR1231.pdf (accessed on 5 September 2018).

54. Trillo, C. Mixed income housing (MIH). In Sustainable Cities and Communities, Encyclopedia of the UN Sustainable Development Goals; W. Leal Filho; Springer: Berlin, Germany, 2019.

(C) 2019 by the authors. Licensee MDPI, Basel, Switzerland. This article is an open access article distributed under the terms and conditions of the Creative Commons Attribution (CC BY) license (http://creativecommons.org/licenses/by/4.0/). 